\title{
Factors of Job Burnout among Female Teachers: A Study on Female Secondary School Teachers in a District of Johor
}

Norshiba Norhisham, Nor Azmawati Husain, Norazira Mohd Abas and Nur Izzati Fatin Haza

To Link this Article: http://dx.doi.org/10.6007/IJARBSS/v11-i8/10438

DOI:10.6007/IJARBSS/v11-i8/10438

Received: 14 June 2021, Revised: 16 July 2021, Accepted: 02 August 2021

Published Online: 10 August 2021

In-Text Citation: (Norhisham et al., 2021)

To Cite this Article: Norhisham, N., Husain, N. A., Abas, N. M., \& Haza, N. I. F. (2021). Factors of Job Burnout among Female Teachers: A Study on Female Secondary School Teachers in a District of Johor. International Journal of Academic Research in Business and Social Sciences, 11(8), 456-467.

Copyright: (C) 2021 The Author(s)

Published by Human Resource Management Academic Research Society (www.hrmars.com)

This article is published under the Creative Commons Attribution (CC BY 4.0) license. Anyone may reproduce, distribute, translate and create derivative works of this article (for both commercial and non-commercial purposes), subject to full attribution to the original publication and authors. The full terms of this license may be seen

at: http://creativecommons.org/licences/by/4.0/legalcode

Vol. 11, No. 8, 2021, Pg. 456 - 467

Full Terms \& Conditions of access and use can be found at http://hrmars.com/index.php/pages/detail/publication-ethics 


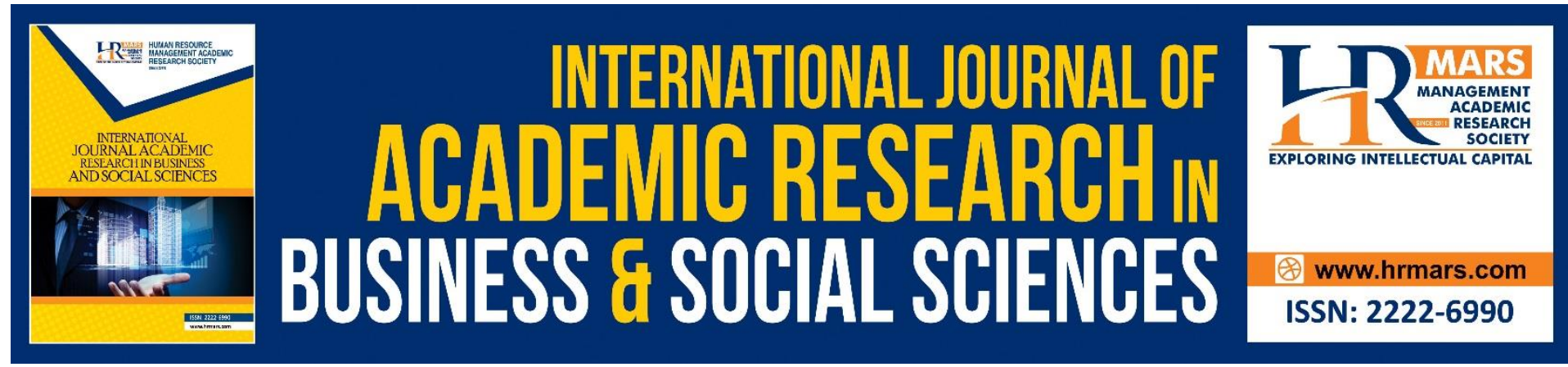

\title{
Factors of Job Burnout among Female Teachers: A Study on Female Secondary School Teachers in a District of Johor
}

\author{
Norshiba Norhisham, Nor Azmawati Husain, Norazira Mohd \\ Abas and Nur Izzati Fatin Haza \\ Universiti Teknologi Mara Cawangan Melaka, Kampus Bandaraya \\ Email: shibahisham@uitm.edu.my,noraz462@uitm.edu.my, aziraabas@uitm.edu.my, \\ izzatifatin1@yahoo.com
}

\begin{abstract}
It is always a belief that a nation's development starts from a good education. Teachers are an important aspect of the education system, supplementing knowledge, and skills to young minds. It is believed that children would be the shaper of the country's future. This put pressure on this profession; the need to provides the best education to children, thus leading them to stress and burnout. Juggling between students' potential, parents' expectations, school administration and personal life lead to job burnout among teachers. As teachers play major role in reshaping future generation, it is important to recognise and acknowledge factors that lead to stress and burnout, thus identifying factors that might prohibits the burnout. This study aims to explore different influencing factors on the work demands of a teacher among female teachers as it holds $70 \%$ of the educator population in Malaysia. Using a correlational study, this paper explores influencing factors to teachers' job burnout from three different aspects: students, environment, and the job itself. 242 female teachers at secondary schools in a district in Malaysia; Muar were included as the respondent. Students' behaviour, work environment, and work overload are hypothesized to be positively correlated with female teachers' job burnout. Pearson Correlation and Multiple Regression were used to test all three hypotheses, where all hypotheses are accepted. The result showed that there is significant relationship between work overload ( $p<0.01, r=.407)$, negative work environment $(p<0.01, r=.423)$ and students' misbehaviour $(p<0.01, r=.569)$ towards female teachers' job burnout. This study also showed that the variance of job burnout among female teacher can be explained by the independent variables tested by $46 \%$. This study is thought to contribute to the topic of burnout in the education context, therefore can add understanding of teachers' well-being and contributes to a healthier workforce. The extension of this study could be done to identify factors that can be taken by the government, schools and individual in order to reduce stress among female teachers.
\end{abstract}

Keywords: Female Teachers, Job Burnout, Student's Misbehaviour, Working Environment, High Workload 


\section{Introduction}

Burnout has been a popular concept to describe the agony of job stress. Much has been written about burnout (Maslach et al., 2009) and there is a continuing drive to assume the factor causing it. Burnout can affect individuals in different ways and can be experienced by all working classes, especially for those whose work demands constant human interactions. Human service professionals, such as doctors, nurses, social services, including teachers reveal to have had and perhaps are still having a hard time. This happens because although the fit between them and their job has been disrupted, they continue their work, and by doing so, may well harm their health and the wellbeing of their clients (Evers et al., 2004). Prior research showed that teachers could experience stress that affected them negatively, physically, or emotionally (Burić et al., 2016). The relational nature of classrooms means that teachers are vulnerable to emotionally draining and discouraging experiences (Maslach and Leiter, 1999). Educators experiencing stress from emotional experiences may also experience physical stress at the same time. In Malaysia, female holds $70 \%$ of the population of secondary school teachers (116,439 from a total of 163,543 teachers) (Global Database Malaysia, 2016). Although teaching, learning, and providing guidance might not be solely emotional practices, they are always irretrievably emotional in character making emotions and emotional labour integral components of the teaching profession (Hargreaves, 2001).

\section{Literature Review}

a) Job burnout

Burnout is defined as a psychological syndrome that involved a prolonged response to a stressor at the workplace (Maslach, 2003). Although the concept of burnout has long been discussed for approximately 30 years i.e. the earliest job burnout writing by Freudenberger (1975) and developed by Maslach and Pines (1977), the topic still among the highlights among the scholars as the implication is varying on several organisational contexts such as performance (i.e. unprofessional doctors (Zhang et al., 2020), well-being such as happiness (Schaufeli et al., 2009) and physical consequences(i.e. health issues) (Ahola et al., 2013). For example, a current study conducted by Bakker and de Vries (2021) expanded the burnout model by searching for alternative resources i.e. leadership and personal resources to reduce the occurrence of burnout among employees. This shows the great effort should be invested in overcoming burnout and it should involve many parties not only employees themselves but also employers as well. In general, individuals who experience burnout is when they reach the maximum level where they can cope with the work stress. In the other words, burnout can be seen through several identified aspects through chronic exhaustion, cynicism and deter work efficacy.

In specific, exhaustion is when individual experience the draining of energetic resources, feel continuous tiredness that is severe and lead to a chronic state of fatigue. Meanwhile, cynicism is when a situation an individual tries to create a gap between them with their work and becoming passive that affect their work attitudes toward a colleague and other peoples related to works. The third criterion is inefficacy, which refers to a feeling where an individual perceives they are not as competent as usual and loses confidence in being successful at work (Bakker and de Vries, 2021). Reviewing from the characteristics of job burnout, we can expect the great impact of burnout if not been mitigate earlier as those employees experiencing burnout psychologically stopping themselves in making them productive and competent. 
Even worst, burnout issues are the most common problems faced by employees in service sectors (Maslach, Schaufeli and Leiter, 2001).

Service employees comprised of numerous professions that are exposed to job burnout the most. Several professions that been highlighted are those employees in helping professions such as teachers (Evers et al., 2004; Kokkinos, 2007), nurses (Greenglass et al., 2001), doctors (Collin et al., 2019; Schaufeli et al., 2009) and police officers (Burke, 1994). Globally, although ample study on burnout has been dedicated specifically to these professions, however, we cannot ignore the fact that several factors such as cultural differences (Schaufeli, 2003; Schaufeli, 2017), possibly lead to inconclusive findings among those job burnout. Some factors are more dominant in certain professions but not in others.

b) Work overload and job burnout

Research so far discovered several causes of job burnout. The most common aspect that commonly relates to job burnout is job demands (Demerouti et al., 2001). A variety of job demands has been highlighted to contribute to job burnout. For example, work overload, work pressure, role ambiguity and many more are general and some are very specific designated according to the professions (Alarcon, 2011). Another school of thought focused more on demographics factors as the causes of burnout such as age, gender, marital status, experience (Bakker et al., 2002; Haque and Aslam, 2011). For example, a study conducted among teachers in Kamrup in rural Australia, discovered age and place of work affect burnout (Goswami, 2013). Even though demographic profiles do have an influence on burnout, yet scholars suggest study should focus on aspects that we can improve such as work characteristics such as job demands (Crawford et al., 2010; Schaufeli and Peeters, 2000)

Focusing on the job demands in regards to job burnout, work overload is one of the job demands that dominantly highlighted especially in helping professionals such as teachers (Yu et al., 2015; Żołnierczyk-Zreda, 2005). Work overload is described as excessive work roles demands (Zhang and Zhu, 2007, p. 489). In detail, teachers are exposed to being overwork and underappreciated, besides the main task for teaching, teachers also responsible to teach an average of four classes a day, with working hours approximately 48 hours a week (Zhang and Zhu, 2007). For example in a study on Finland teachers, Hakanen et al. (2006) discovered work overload together with student misbehaviour affect teacher health through burnout. Although the teaching profession is known as a profession that requires a lot of commitment, in this present study we incorporate gender aspects as less likely to be found job burnout study that focuses on female teachers only except Noor and Zainuddin (2011) study. Hence, we formulate the below hypothesis.

\section{Hypothesis 1: Work overload has a significant effect towards female teachers' job burnout}

c) Negative work environment and job burnout

Scholars state that organizational factors in the work context may be a cause of chronic stress that leads to job burnout (Cherniss, 1980 and Schaufeli and Enzmann ,1993). If a work environment is unable to meet individuals' needs, this can reduce their energy and enthusiasm, thus leading to negative consequences such as high absenteeism, poor job performance, mental diseases, anxiety, and job-related injuries (Freudenberger, 1980; Clarke et al., 2003; Glasberg et al., 2007). 
The causes of burnout are more linked with the psychosocial work environment (work overload, lack of job control, low job social support, lack of autonomy, time pressure, much direct patient contact, etc.), rather than with personal factors (Schaufeli, 1999; Stansfeld et al., 1999; Ramírez et al., 1995, 1996; Visser et al., 2003; Sibbald et al., 2003; Greenglass et al., 1998; Imai et al., 2004).

The World Health Organization (WHO) defines burnout as an occupational phenomenon, noting its inherent relationship to the workplace, and describes it as feeling emotionally exhausted, cynical, and ineffective in relation to one's work, colleagues, and clients (World Health Organization (W.H.O.), 2019; Maslach and Jackson, 1981; Maslach et al., 1986). Unlike stress, the WHO recommends that burnout not be adapted for a personal context, but remain reserved as a phenomenon associated with work (World Health Organization (W.H.O), 2019). Burnout has been shown to be the consequence of a poorly designed work environment regardless of occupation, indicating that burnout is less about the type of work, but rather how the work is designed, distributed, and managed (Maslach et al., 2001). According to Maslach et al (2009) the response to chronic stress at both the personal level and in terms of working relations triggers burnout syndrome, which is characterized by emotional exhaustion, depersonalization and diminished personal accomplishment.

Burnout has been examined in a variety of human service professions including education and healthcare. According to Rugulies (2019), the psychosocial work environment is key research held for understanding how the interrelations of societal structures, environmental exposures, and psychological and psychophysiological processes affect the health and illness of workers, which has potential impacts in terms of wellbeing and discomfort (e.g., job satisfaction, stress, burnout) (Appelbaum et al., 2019).

In the healthcare industry, in order to provide safe, high-quality care, nurses need the resources and support to do so, otherwise, they become overextended, resulting in burnout. While there have been prior calls to transform work environments to improve the delivery and safety of patient care (Donaldson et al,2000 and Institute of Medicine (IOM), 2001), recent efforts by the National Academy of Medicine (National Academies of and Medicine (NAM), 2019) and other researchers highlight the natural synergy between clinician wellbeing and better patient outcomes. Amelia et al (2021) suggest that hospital administrators have to simultaneously alleviate nurse burnout and improve patient outcomes could achieve by improving their work environments. Thus, a negative work environment has a significant impact towards job burnout.

Hypothesis 2: Work environment has a significant effect towards female teachers' job burnout

d) Students misbehaviour and job burnout

One of the factors related most strongly to teacher burnout is misbehaviour among students. (Burke et al., 1996; Friedman, 1995). Student misbehaviour defined as behaviours that disrupt the teaching-learning process or interfere with the orderly operation of the classroom (Finn et al., 2008; Houghton et al., 1988; Thompson, 2009). Examples of misbehaviour include skipping or being late to class, disrupting instruction (e.g., speaking out of turn, swearing, getting out of the seat without permission), verbal abuse or disrespect toward teachers, 
noncompliance (i.e., failure to follow directions), off-task behaviour, bullying, harassment, and gang activity (Bru et al., 2002; Fernet et al., 2012; Finn et al., 2008; Robers et al., 2012).

Student misbehaviour has been associated with reduced instructional time, job dissatisfaction, stress, lack of efficacy, and burnout (Friedman, 1995; Little, 2005; Little and Hudson, 1998; Miller et al., 2000; Poulou and Norwich, 2000). A more recent study by McCormick and Barnett (2011) reported student misbehaviour as the most salient stressor related to teacher burnout.

With specific regard to teachers' work, it is important to note that emotional requests are strongly involved in the teaching profession and educational issues leading to consider caringfor-others the main part of their job (Johnson et al., 2005; Morse et al., 2012; and Schaufeli et al., 2008). With this regard, teacher-students' relationships are significantly related to burnout risk. Students' misbehaviour, indeed, was considered the main stressful event affecting teachers' well-being. According to several authors, teachers' negative emotional experience occurring when students misbehave was strongly related to teachers' burnout (Chang, 2013; Chang, 2009; Tsouloupas et al., 2010). Consistently, some studies showed that the stronger the negative emotions, the more intense the burnout symptoms reported by the teachers (Chiacchio et al., 2006; Curchod-Ruedi, 2010).

The relationship between student misbehaviour and teacher burnout is dynamic and is influenced by the teacher's appraisal of the behaviour, perceived self-efficacy and methods employed to control the behaviour, and the resulting impact on the behaviour, relationship, and classroom climate. Teachers' management of the misbehaviour not only affects the behaviour itself (Bru et al., 2002), but also the classroom environment (Avtgis and Rancer, 2008) and the relationship between the students and the teacher (Marzano et al., 2003).

In previous research, several models have been proposed to explain the complex relationship between student misbehaviour and teacher burnout. Chang (2009) argues that the habitual pattern in teachers' appraisals of the misbehaviour can cause (a) anger when perceived as caused by the student with a high control potential, (b) guilt and shame when perceived as caused by the teacher with high control potential, (c) frustration when viewed as caused by circumstances with low control potential, or anxiety when encountering new and uncertain situations. These repeated experiences of feeling guilt, frustration, anxiety, and anger in response to student misbehaviour led to emotional exhaustion and other aspects of burnout.

Another model, proposed by Fernet et al (2012), uses self-determination theory to articulate how misbehaviour impedes teachers' intrinsic motivation by reducing their autonomous motivation and sense of self-efficacy, which leads to emotional exhaustion and higher levels of burnout. According to Tatiana (2021), lecturers with a higher ability of regulation of emotions are better equipped to deal with the intense emotion-laden demands of their work (e.g., student misbehaviour: interruptions, rule violations and also relationships with leaders) that may increase tension, resistance, exhaustion and decrease job satisfaction.

With specific regard to teachers' work, it is important to note that emotional requests are strongly involved in the teaching profession and educational issues leading to consider caringfor-others the main part of their job (Johnson et al., 2005; Morse et al., 2012; and Schaufeli 
et al., 2008). With this regard, teacher-students' relationships are significantly related to burnout risk. Students' misbehaviour, indeed, was considered the main stressful event affecting teachers' well-being. According to several authors, teachers' negative emotional experience occurring when students misbehave was strongly related to teachers' burnout (Chang, 2013; Chang, 2009; and Tsouloupas et al., 2010). Consistently, some studies showed that the stronger the negative emotions, the more intense the burnout symptoms reported by the teachers (Chiacchio et al., 2006; Curchod-Ruedi, 2010).

Hypothesis 3: Students misbehaviour has a significant effect towards female teachers' job burnout

\section{Research Framework}

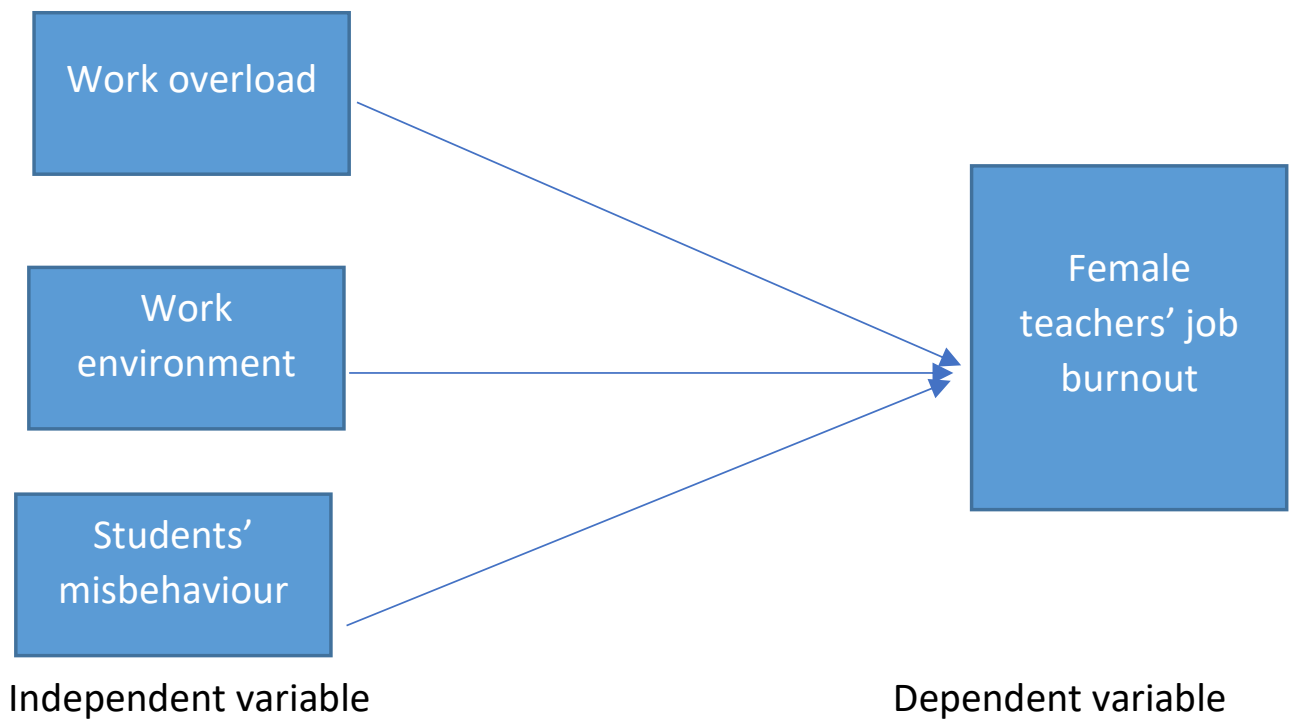

\section{Methodology}

A designated questionnaire survey instrument was used to assess the determinants that influence female school teachers' burnout factor. The intended target population, in order to conduct the research, is female-secondary school teachers in Muar, Johor. There are 763 female-secondary school teachers in the district (from 20 secondary schools) and 254 samples are sufficient to become respondents (Krejcie and Morgan, 1970). A total of 27 items were adapted from several sources (Table 1) and each variable obtained a sufficient Cronbach Alpha's value in their reliability test (Sekaran and Bougie, 2013). 
Table 1: Cronbach's Alpha value for variables

\begin{tabular}{|l|c|c|}
\hline Variable & $\begin{array}{l}\text { Cronbach Alpha } \\
\text { value } \\
\text { (Sekaran and Bougie, } \\
\text { 2013) }\end{array}$ & No. of items \\
\hline $\begin{array}{l}\text { Job burnout (Maslach, Jackson \& Schwab, } \\
\text { 1986) }\end{array}$ & .827 & 6 \\
\hline Work overload (Houston et al., 2004) & .754 & 4 \\
\hline Work environment (Raja Tayeh, 2013) & .796 & 6 \\
\hline $\begin{array}{l}\text { Students misbehaviour (Maslach, Jackson \& } \\
\text { Schwab, 1986) }\end{array}$ & .789 & 11 \\
\hline
\end{tabular}

\section{Findings}

A total of 254 questionnaires were distributed to the respondents and 242 completed questionnaires were returned (95.3\% return rate). Table 2 shows the respondents for the study. The majority of the respondents are married (83.5\%), Malay (64\%) with $5-12$ years of teaching experience (40.6\%).

a) Respondents' profile

Table 2: Respondent profile

\begin{tabular}{|l|l|c|c|}
\hline & Category & No. of respondents & Percentage (\%) \\
\hline Status & Single & 36 & 14.9 \\
\hline & Married & 202 & 83.5 \\
\hline & Divorced & 4 & 1.7 \\
\hline Race & Malay & 156 & 64.5 \\
\hline & Chinese & 76 & 31.6 \\
\hline & Indian & 9 & 4.1 \\
\hline Year of service & Others & 1 & 0.4 \\
\hline & $1-4$ years & 16 & 6.6 \\
\hline & $5-12$ years & 98 & 40.6 \\
\hline & $13-20$ years & 53 & 21.9 \\
\hline & $21-28$ years & 49 & 20.2 \\
\hline & More than 29 years & 26 & 10.7 \\
\hline
\end{tabular}

$\mathrm{N}=242$ respondents

b) Correlation analysis

The correlational analysis was used in this research to measure the relationship between the variables. The co-relational coefficients of the four variables are as follows: 
Table 3: Correlation coefficient of work overload, work environment and student misbehaviour with job burnout

\begin{tabular}{|l|l|l|l|l|}
\hline Variable & 1 & 2 & 3 & 4 \\
\hline 1. Job burnout & & .407 & .423 & .569 \\
\hline 2. Work overload & .407 & & .077 & .215 \\
\hline 3. Negative work environment & .423 & .077 & & .367 \\
\hline 4. Students' misbehaviour & .569 & .215 & .367 & \\
\hline
\end{tabular}

${ }^{* *}$ Correlation is significant at the 0.01 level (2-tailed).

The correlation test showed that all independent variables have a positive relationship with job burnout among female secondary teachers. The $r$ value for work overload is 0.407 with $p$ value $=.000$ at the level of $p<0.01$ (Pallant, 2016). The $r$ value for work environment is 0.423 with $p$ value $=.000$ at the level of $p<0.01$ (Pallant, 2016) and students' misbehaviour is 0.569 with $p$ value $=.000$ at the level of $p<0.01$ (Pallant, 2016).

Table 4: Regression analysis for work overload, negative work environment and students' misbehaviour

\begin{tabular}{|c|c|c|c|c|c|}
\hline \multirow[t]{2}{*}{ Model } & \multicolumn{2}{|c|}{ Unstandardized Coefficients } & \multirow{2}{*}{$\begin{array}{l}\text { Standardized } \\
\text { Coefficients } \\
\text { Beta }\end{array}$} & \multirow[t]{2}{*}{$\mathrm{t}$} & \multirow[t]{2}{*}{ Sig. } \\
\hline & $B$ & Std. Error & & & \\
\hline (Constant) & .654 & .211 & & 3.104 & .002 \\
\hline Work overload & .223 & .036 & .200 & 6.134 & .000 \\
\hline $\begin{array}{l}\text { Negative work } \\
\text { environment }\end{array}$ & .245 & .050 & .248 & 4.859 & .000 \\
\hline $\begin{array}{l}\text { Students' } \\
\text { misbehaviour }\end{array}$ & .314 & .040 & .414 & 7.933 & .000 \\
\hline
\end{tabular}

a. Dependent Variable: BURNOUT

\begin{tabular}{|l|l|l|l|l|l|}
\hline Model & $\mathrm{R}$ & R Square & $\begin{array}{l}\text { Adjusted } \\
\text { Square }\end{array}$ & $\begin{array}{l}\text { Std. Error of th } \\
\text { Estimate }\end{array}$ \\
\hline 1 & .680 & .462 & .455 & .35277 \\
\hline
\end{tabular}

Hypothesis 1, 2 and 3 predicted that job burnout is affected by work overload, negative work environment and students' misbehaviour. According to Table 4, multiple regression analysis was used to assess the association between three variables (work overload, negative work environment and students' misbehaviour) towards teachers' job burnout. The $R^{2}=0.46$ which means $46 \%$ of the variance of job burnout (dependent variable) can be explained by the independent variables (work overload, negative work environment and students' misbehaviour) while the remaining $54 \%$ can be explained by other variables. All independent variables are significant with job burnout where $\beta=0.22$ (work overload), $\beta=0.45$ (negative work environment) and $\beta=0.31$ (students' misbehaviour) at the level of $p<0.001$. Therefore, all hypotheses are supported.

\section{Conclusion}

The key finding in this study is all independent variables give an impact on job burnout. The result shows that all factors (work overload, negative work environment and students' misbehaviour) chosen in this study have a significant impact towards job burnout. This 
research shows that the most significant variable of the factor that contributes to burnout among female teachers is students' misbehaviour. This aligns with findings by Gold et al. (2010), Shin et al. (2013) and Manso-Pinto (2001) where they have linked the students' misconduct at school with a high level of internalization behaviours and teachers' stress. Ability to manage the behaviour of students is important to give better exposure to teachers in handling the students. Schools are to be expected to play parts in managing the behaviour of students, with the help of parents. Teachers also need to be able to manage their own time and stress to reduce the anxiety that they are feeling. Knowledge in time management also needed for the employees to be able to apply in their working environment thus minimizing their job burnout.

\section{References}

Ahola, K., Salminen, S., Toppinen-Tanner, S., Koskinen, A., \& Väänänen, A. (2013). Occupational burnout and severe injuries: An eight-year prospective cohort study among Finnish forest industry workers. Journal of Occupational Health, 55(6), 450457. doi: 10.1539/joh.13-0021-OA

Alarcon, G. M. (2011). A meta-analysis of burnout with job demands, resources, and attitudes. Journal of Vocational Behavior, 79(2), 549-562. doi: http://dx.doi.org/10.1016/j.jvb.2011.03.007

Bakker, A. B., \& de Vries, J. D. (2021). Job Demands-Resources theory and self-regulation: new explanations and remedies for job burnout. Anxiety, Stress, \& Coping, 34(1), 121. doi: $10.1080 / 10615806.2020 .1797695$

Bakker, A. B., Demerouti, E., \& Schaufeli, W. B. (2002). Validation of the Maslach Burnout Inventory - General Survey: An Internet Study. Anxiety, Stress, \& Coping, 15(3), 245260. doi: $10.1080 / 1061580021000020716$

Burke, R. J. (1994). Stressful Events, Work-Family Conflict, Coping, Psychological Burnout, and Well-Being among Police Officers. Psychological Reports, 75(2), 787-800. doi: 10.2466/pro.1994.75.2.787

Burke, R. J., \& Greenglass, E. (1995). A longitudinal study of psychological burnout in teachers. Human Relations, 48(2), 187-202.

Burke, R. J., Greenglass, E. R., \& Schwarzer, R. (1996). Predicting teacher burnout over time: Effects of work stress, social support, and self-doubts on burnout and its consequences. Anxiety, Stress and Coping, 9, 261-275.

Bru, E., Stephens, P., \& Torsheim, T. (2002). Students' perceptions of class management and reports of their own misbehavior. Journal of School Psychology, 40, 287-307.

Collin, V., Toon, M., O'Selmo, E., Reynolds, L., \& Whitehead, P. (2019). A survey of stress, burnout and well-being in UK dentists. British Dental Journal, 226(1), 40-49. doi: 10.1038/sj.bdj.2019.6

Crawford, E. R., LePine, J. A., \& Rich, B. L. (2010). Linking job demands and resources to employee engagement and burnout: A theoretical extension and meta-analytic test. Journal of Applied Psychology, 95(5), 834-848. doi: 10.1037/a0019364

Demerouti, E., Bakker, A. B., Nachreiner, F., \& Schaufeli, W. B. (2001). The job demandsresources model of burnout. Journal of Applied Psychology, 86(3), 499. doi: http://dx.doi.org/10.1037/0021-9010.86.3.499

Evers, W. J. G., Tomic, W., \& Brouwers, A. (2004). Burnout among Teachers:Students' and Teachers' Perceptions Compared. School Psychology International, 25(2), 131-148. doi: $10.1177 / 0143034304043670$ 
Fernet, C., Guay, F., Senecal, C., \& Austin, S. (2012). Predicting intraindividual changes in teacher burnout: The role of perceived school environment and motivational factors. Teaching and Teacher Education: An International Journal of Research and Studies, 28(4), 514-525.

Finn, J. D., Fish, R. M., \& Scott, L. A. (2008). Educational sequelae of high school misbehavior. Journal of Educational Research, 101, 259-274. http://dx.doi.org/10.3200/JOER.101.5.259-274

Freudenberger, H. J. (1975). The staff burn-out syndrome in alternative institutions. Psychotherapy: Theory, Research \& Practice, 12(1), 73-82. doi: 10.1037/h0086411

Freudenberger H. Burnout: The high cost of achievement. New York: Anchor Press; 1980.

Goswami, M. (2013). A study of burnout of secondary school teachers in relation to their job satisfaction. Journal Of Humanities And Social Science, 10(1), 18-26.

Greenglass, E. R., Burke, R. J., \& Fiksenbaum, L. (2001). Workload and burnout in nurses. Journal of Community \& Applied Social Psychology, 11(3), 211-215. doi: https://doi.org/10.1002/casp.614

Hakanen, J. J., Bakker, A. B., \& Schaufeli, W. B. (2006). Burnout and work engagement among teachers. Journal of School Psychology, 43(6), 495-513. doi: https://doi.org/10.1016/j.jsp.2005.11.001

Haque, A., \& Aslam, M. S. (2011). The influence of demographics on job burnout. Far East Journal of Psychology and Business, 4(2), 57-72.

Houghton, S., Wheldall, K., \& Merrett, F. (1988). Classroom behaviour problems which secondary school teachers say they find most troublesome. British Educational Research Journal, 14(3), 297-312.

Imai, H., Nakao, H., Tschiya, M., Kuroda, Y., Katoh, T. (2004) Burnout and work environments of public health nurses involved in mental health care. Occup Environ Med 61:764768

Kokkinos, C. M. (2007). Job stressors, personality and burnout in primary school teachers. British Journal of Educational Psychology, 77(1), 229-243. doi: https://doi.org/10.1348/000709905X90344

Little, E. (2005). Secondary school teachers' perceptions of students' problem behaviours. Educational Psychology, 25, 369-378.

Little, E., \& Hudson, A. (1998). Conduct problems and treatment across home and school: A review of the literature. Behaviour Change, 14, 213-227

Maslach, C. (2003). Job Burnout. Current Directions in Psychological Science, 12(5), 189-192. doi: $10.1111 / 1467-8721.01258$

Maslach, C., \& Pines, A. (1977). The burn-out syndrome in the day care setting. Child care quarterly, 6(2), 100-113.

Maslach, C., Schaufeli, W. B., \& Leiter, M. P. (2001). Job burnout. Annual Review of Psychology, 52(1), 397-422.

Miller, A., Ferguson, E., \& Byrne, I. (2000). Pupils' causal attributions for difficult classroom behaviour. British Journal of Educational Psychology, 70, 85-96

Noor, N. M., \& Zainuddin, M. (2011). Emotional labor and burnout among female teachers: Work-family conflict as mediator. Asian Journal of Social Psychology, 14(4), 283-293. doi: https://doi.org/10.1111/j.1467-839X.2011.01349.

Poulou, M., \& Norwich, B. (2000). Teachers' causal attributions cognitive, emotional and behavioral responses to students with emotional and behavioural difficulties. British Journal of Educational Psychology, 70, 559-581 
Ramı'rez, A., Graham, J., Richards, M., Cull, A., Gregory, W., Leaning, M., Snashal, D., Timothy, A. (1995) Burnout and psychiatric disorder among cancer clinicians. Br J Cancer 71:1263-1269

Robers, S., Zhang, J., Truman, J., \& Snyder, T. D. (2012). Indicators of school crime and safety: 2011 (NCES 2012-002/NCJ 236021). National Center for Education Statistics, U.S. Department of Education, and Bureau of Justice Statistics, Office of Justice Programs, U.S. Department of Justice. Washington, DC

Schaufeli, W. B. (2003). Past performance and future perspectives of burnout research. SA Journal of Industrial Psychology, 29(4), 1-15.

Schaufeli, W. B. (2017). Applying the Job Demands-Resources model: A 'how to' guide to measuring and tackling work engagement and burnout. Organizational Dynamics, 46(2), 120-132. doi: https://doi.org/10.1016/j.orgdyn.2017.04.008

Schaufeli, W. B., Bakker, A. B., van der Heijden, F. M. M. A., \& Prins, J. T. (2009). Workaholism, burnout and well-being among junior doctors: The mediating role of role conflict. Work and Stress, 23(2), 155-172. doi: 10.1080/02678370902834021

Schaufeli, W. B., \& Peeters, M. C. W. (2000). Job Stress and Burnout Among Correctional Officers: A Literature Review. International Journal of Stress Management, 7(1), 1948. doi: 10.1023/A:1009514731657

Sibbald, B., Bojke, C., Gravelle, H. (2003) National survey of job satisfaction and retirement intentions among general practitioners in England. BMJ 326:22

Stansfeld, S., Fuhrer, R., Shipley, M., Marmot, M. (1999) Work characteristics predict psychiatric disorder: prospective results from the whitehall II study. Occup Environ Med 56:302-307

Thompson, B. (2009). Disruptive behaviours in Barbadian classrooms: Implications for universal secondary education in the Caribbean. Journal of Eastern Caribbean Studies, 34(3), 39-58

Visser, M., Smets, E., Oort, F., De Haes, H. (2003) Stress, satisfaction and burnout among Dutch medical specialists. CMAJ 168:271-275

World Health Organization (W.H.O). Burn-Out An "Occupational Phenomenon": International Classification of Diseases. Available online: https://www.who.int/mental_health/evidence/burn-out/en/ (accessed on 29 September 2019).

Yu, X., Wang, P., Zhai, X., Dai, H., \& Yang, Q. (2015). The Effect of Work Stress on Job Burnout Among Teachers: The Mediating Role of Self-efficacy. Social Indicators Research, 122(3), 701-708. doi: 10.1007/s11205-014-0716-5

Zhang, Q., \& Zhu, W. (2007). Teacher stress, burnout, and social support in Chinese secondary education. Human Communication, 10(4), 487-496.

Zhang, S. E., Wang, J., Xie, F., Yin, D., Shi, Y., Zhang, M., . . Sun, T. (2020). A cross-sectional study of job burnout, psychological attachment, and the career calling of Chinese doctors. BMC Health Services Research, 20(1), 193. doi: 10.1186/s12913-020-4996-y

Żołnierczyk-Zreda, D. (2005). An Intervention to Reduce Work-Related Burnout in Teachers. International Journal of Occupational Safety and Ergonomics, 11(4), 423-430. doi: 10.1080/10803548.2005.11076661 